\title{
Antimicrobial Potential of Ozone in an Ultrasonic Cleaning System Against Staphylococcus aureus
}

\author{
Carlos ESTRELA ${ }^{1}$ \\ Cyntia R.A. ESTRELA ${ }^{1}$ \\ Daniel de Almeida DECURCIO ${ }^{1}$ \\ Julio Almeida SILVA ${ }^{1}$ \\ Lili Luschke BAMMANN² \\ ${ }^{1}$ Faculty of Dentistry, Federal University of Goiás, Goiânia, GO, Brazil \\ ${ }^{2}$ Faculty of Dentistry, Federal University of Pelotas, Pelotas, RS, Brazil
}

\begin{abstract}
The aim of this study was to evaluate the antimicrobial potential of ozone applied to 3 different solutions in an ultrasonic cleaning system against Staphylococcus aureus. A total of $120 \mathrm{~mL}$ of $S$. aureus were mixed in $6 \mathrm{~L}$ of the experimental solutions (sterilie distilled water, vinegar and sterile distilled water + Endozime AWpluz) used in a ultrasonic cleaning system (UCS). Ozone was produced by an electric discharge through a current of oxygen and bubbling with flow rate at $7 \mathrm{~g} / \mathrm{h}$ ozone (1.2\%) into the microbial suspensions. Ten $\mathrm{mL}$ of each experimental suspension were collected and 5 fold dilutions were made in $9 \mathrm{~mL}$ of $\mathrm{BHI}$ and incubated at $37^{\circ} \mathrm{C}$ for $48 \mathrm{~h}$. Bacterial growth was evaluated by turbidity of the culture medium. At the same time, $1 \mathrm{~mL}$ of bacterial samples was collected and inoculated in BHIA plates. After incubation at $37^{\circ} \mathrm{C}$ for $48 \mathrm{~h}$, the number of colony forming units (cfu) per mL on BHIA surface was counted. In dilution test in BHI tubes and in BHIA plates (cfu/mL), bacterial growth was not observed in any of the experimental solutions when ozone was added. Under the tested conditions, it may be concluded that the addition of ozone to a ultrasonic cleaning system containing different experimental solutions resulted in antibacterial activity against S. aureus.
\end{abstract}

Key Words: ozone, ultrasonic cleaner system, water disinfection, Staphylococcus aureus, dental treatment units.

\section{INTRODUCTION}

Special attention must be given to biosecurity in Endodontics in order to prevent several diseases that can be caused by dissemination of harmful pathogens.

For a disease to be transmitted, it is necessary a source of infecting microorganisms, a susceptible host and a microbial transmission route. The prevalence and incidence of microbial cross-infection in dental environment has been well documented. Dental personnel do not seem to take the problem of cross-infection as seriously as they should, and may transmit or acquire more infections than they realize (1). The Centers for Disease Control and Prevention (CDC), which is one of the 13 major operating components of the US Department of Health and Human Services (HHS), have established guidelines for infection control (2).
The high frequency, deleterious effects and infection parameters of HIV and hepatitis viruses highlight the importance of finding effective infection control measures for routine application in endodontic procedures. Willians et al. (3) examined the quality of the water delivered by dental units and the compliance of practitioners with the recommended disinfection protocols. Most of the 24 clean-water dental units surveyed were contaminated with a large numbers of microorganisms. When units were properly disinfected and supplied with sterile water, they delivered clean, noncontaminated water for at least 1 week. This suggests that contaminated units had not been properly disinfected on a weekly basis as recommended and had also been filled with water that was not free of bacteria. Clinicians should be aware that following strict disinfection protocols effectively minimizes bacterial contami-

Correspondence: Prof. Dr. Carlos Estrela, Centro de Ensino e Pesquisa Odontológica do Brasil (CEPOBRAS), Rua C-245, Quadra 546, Lote 9, Jardim América, 74290-200 Goiânia, GO, Brasil. Tel/Fax: +55-62-3251-0408. e-mail: estrela3@terra.com.br 
nation of the water delivered by clean water dental units. When these protocols are not followed, the benefits of the clean-water systems are negated and it can be expected that contamination will occur in a similar way to that of typical dental units.

Several precautions have been recommended specially based on the findings of epidemiologic studies on microbial transmission in dental office environment. Dental units may contain infecting agents that can be spread over the dental team, instruments, equipments and materials within the operative field. According to their potential of infection transmission, dental instruments are classified in critical, semicritical and noncritical. Several instruments used in endodontic procedures are considered as critical $(1,4)$.

Sterilization of dental instruments has been performed by different methods. Autoclave sterilizers using steam under pressure as antimicrobial agent have been the most recommended. However, various instruments, such as endodontic instruments, files and burs, precleaned before any sterilization or disinfection procedure to reduce microbial contamination. The ultrasonic cleaner cycle (UCS) has been proved effective on previously cleaned or debrided instruments. The ultrasonic energy (cavitating action) is produced by alternating high and low pressure waves generated by high frequency (ultrasonic) sound resulting from formation and collapsing of billions of tiny bubbles in a cleaning solution and creates high turbulence at the surface of the instrument. This process dislodges the debris and either dissolves or suspends them in solution (4).

Alternatives have been suggested for infection control, like use of ozonated water. Ozone properties are expected to be useful in dentistry, although more studies are required to assess its benefits as an effective antimicrobial agent. Ozone is a blue gas, containing 3 oxygen atoms. It is irritant, toxic, very reactive and instable, needing to be incorporated to other substances. Studies have reported interesting results when ozonetreated water was used in vitro and in dental units (5-9).

Studies addressing the use of ozone in infection control in dentistry are necessary because its effectiveness is still unknown. The aim of this study was to assess the antimicrobial potential of ozone applied to 3 different solutions in an ultrasonic cleaning system against Staphylococcus aureus.

\section{MATERIAL AND METHODS}

One reference bacterial strain - Staphylococcus aureus (ATCC 6538, facultative aerobic gram-positive coccus) obtained from the American Type Culture Collection was used in the study. The strain was inoculated in $9 \mathrm{~mL}$ of brain heart infusion (BHI; Difco Laboratories, Detroit, MI, USA), incubated at $37^{\circ} \mathrm{C}$ for $24 \mathrm{~h}$ and subcultured on the surface of brain heart infusion agar (BHIA; Difco Laboratories), followed by the same incubation conditions. Cells grown on BHIA were scraped off the surface and suspended in saline to give a final concentration of approximately $3 \times 10^{8}$ cells/ $\mathrm{mL}$ adjusted to No. 1 MacFarland turbidity standard.

The antibacterial effect of ozone applied to 3 solutions in an ultrasonic cleaning system (BIO3; Odontobrás Ind. Com. Equip. Med. Odont. Ltda, Ribeirão Preto, SP, Brazil) was assessed using 6 experimental and 2 control groups (experimentally contaminated and sterilie distilled water at $40^{\circ} \mathrm{C}$ were used as positive and negative controls, respectively) (Table 1).

Table 1. Control and experimental groups.

\begin{tabular}{ll}
\hline Groups & Solutions tested in the ultrasonic cleaner system \\
\hline 1 & Ozonated sterilized distilled water at $40^{\circ} \mathrm{C}$ mixed with $S$. aureus \\
2 & Ozonated sterilized distilled water at $60^{\circ} \mathrm{C}$ mixed with $\mathrm{S}$. aureus \\
3 & Ozonated vinegar* at $40^{\circ} \mathrm{C}$ mixed with $\mathrm{S}$. aureus \\
4 & Ozonated vinegar* at $60^{\circ} \mathrm{C}$ mixed with $\mathrm{S}$. aureus \\
5 & Ozonated sterilized distilled water + Endozime AWpluz** at $40^{\circ} \mathrm{C}$ mixed with $S$. aureus \\
6 & Sterilized distilled water + Endozime AWpluz** at $40^{\circ} \mathrm{C}$ mixed with $S$. aureus \\
7 & Distilled water at $40^{\circ} \mathrm{C}$ mixed with S. aureus (positive control) \\
8 & Sterilized distilled water at $40^{\circ} \mathrm{C}$ (negative control) \\
\hline
\end{tabular}

*Toscano Apple Vinegar; Toscano, São Paulo, SP, Brazil; ** DFL Ind. Com., Petrópolis, RJ, Brazil. 
A total of $120 \mathrm{~mL}$ of the bacterial experimental suspension (concentration of $3 \times 10^{8}$ cells $/ \mathrm{mL}$ ) were mixed with $6 \mathrm{~L}$ of the experimental solutions used in the ultrasonic cleaner (dilution ratio 1:50; $20 \mathrm{~mL}$ bacterial suspension in $1 \mathrm{~L}$ water), which was activated according to the manufacturer's specifications, i.e., sonication for 20 min with solutions at $40^{\circ} \mathrm{C}$. In groups 2 and 4 , the temperature was raised to $60^{\circ} \mathrm{C}$. Ozone was produced by electric discharge through oxygen current (PXZ3507, Eaglesat Tecnologia em Sistemas Ltda., São José dos Campos, SP, Brazil) and bubbled into $1 \mathrm{~L}$ sterile distilled water at $7 \mathrm{~g} / \mathrm{h}$ ozone flow rate $(1.2 \%)$ into the standard bacterial suspensions ( $3 \mathrm{X} 10^{8}$ cells $/ \mathrm{mL}$ ).

After ultrasonication (20 min), $10 \mathrm{~mL}$ of each experimental suspension were collected and 10 fold dilutions were prepared in 9 $\mathrm{mL}$ of $\mathrm{BHI}$ and incubated at $37^{\circ} \mathrm{C}$ for 48 h. Bacterial growth was evaluated by turbidity of the culture medium. Then, $1 \mathrm{~mL}$ of inoculum from these "cultures" was transferred to $9 \mathrm{~mL}$ of BHI, under identical incubation conditions, for double checking bacterial growth and multiplication. Bacterial viability was macroscopically evaluated by culture medium turbidity and microscopically determined by Gram staining when necessary. At the same time, $1 \mathrm{~mL}$ of each experimental and control groups was collected and spread on the surface of BHIA, previously poured in Petri plates, using sterile swabs. After incubation at $37^{\circ} \mathrm{C}$ for $48 \mathrm{~h}$, the plates containing more than 50 colony forming units (cfu) on agar surface were selected and the total number of cfu was determined.

All collections were carried out in triplicate under aseptic conditions.

\section{RESULTS}

The results of the solutions tested in the ultrasonic cleaning system are shown in Tables 2 and 3. The dilution tests in BHI and BHIA (cfu/mL) showed that ozone was effective in eliminating S. aureus. Bacteria were viable in the positive control group, while in the negative control group distilled water was free of microorganisms under the experimental conditions.

\section{DISCUSSION}

Personal protection guidelines for oral health staff and patients within clinical environments are aimed at preventing microbial infection and cross-infection during dental practice. All members of the staff are susceptible to many diseases in the office setting (10).

A basic rule for infection control is "do not disinfect when you can sterilize" (1). Important recommendations must be daily observed and standard precautions are the primary strategy for successful noso-
Table 2. Influence of ozone in UCS with contaminated solutions.

\begin{tabular}{lccccc}
\hline Groups & \multicolumn{5}{c}{ Dilution test in BHI tubes } \\
\cline { 2 - 6 } & $10^{-1}$ & $10^{-2}$ & $10^{-3}$ & $10^{-4}$ & $10^{-5}$ \\
& dilution & dilution & dilution & dilution & dilution \\
\hline 1 & -- & -- & -- & -- & -- \\
2 & -- & -- & -- & -- & -- \\
3 & -- & -- & -- & -- & - \\
4 & -- & -- & -- & -- & - \\
5 & -- & -- & -- & -- & - \\
6 & ++ & ++ & ++ & ++ & ++ \\
7 & ++ & ++ & ++ & ++ & ++ \\
8 & -- & -- & -- & -- & - \\
\hline
\end{tabular}

BHI= brain heart infusion. $(++)$ Positive result = growth presence/ineffectiveness; $(--)$ Negative result $=$ growth absence/effectiveness .

Table 3. Cfu/mL counted on BHIA surface (values greater than $50 \mathrm{cfu} / \mathrm{mL}$ ).

\begin{tabular}{lccccc}
\hline Groups & \multicolumn{5}{c}{ Dilution test in BHIA plates } \\
\cline { 2 - 6 } & $\begin{array}{c}10^{-1} \\
\text { dilution }\end{array}$ & $\begin{array}{c}10^{-2} \\
\text { dilution }\end{array}$ & $\begin{array}{c}10^{-3} \\
\text { dilution }\end{array}$ & $\begin{array}{c}10^{-4} \\
\text { dilution }\end{array}$ & $\begin{array}{c}10^{-5} \\
\text { dilution }\end{array}$ \\
\hline 1 & 0 & 0 & 0 & 0 & 0 \\
2 & 0 & 0 & 0 & 0 & 0 \\
3 & 0 & 0 & 0 & 0 & 0 \\
4 & 0 & 0 & 0 & 0 & 0 \\
5 & 0 & 0 & 0 & 0 & 0 \\
6 & $>500$ & $>500$ & $>500$ & $>500$ & $>500$ \\
7 & $>500$ & $>500$ & $>500$ & $>500$ & $>500$ \\
8 & 0 & 0 & 0 & 0 & 0 \\
\hline
\end{tabular}

BHIA= brain heart infusion agar. 
comial infection control. In second tier are precautions designed only for treatment of specified patients, i.e., those known or suspected to be infected or colonized with epidemiologically important pathogens that can be transmitted by airborne or droplet transmission or by contact with dry skin or contaminated surfaces (11).

Contaminated instruments are at high risk for disease spread through accidental cuts or punctures. Therefore, decontamination before sterilization is important because it reduces the microbial population, the risk for contamination and transmission, the risk for work accident, etc. Ultrasonic cleaning enhances the removal of microorganisms from blood, saliva, dirty instruments with sealers and others materials. The association of cleaning and disinfection is the best strategy to significantly reduce the number of viable microorganisms. The use of ozone is justified as a new option of agent with antimicrobial action.

The findings of this study showed that use of ozone in an ultrasonic cleaning system containing either sterilized distilled water, vinegar or sterilized distilled water + Endozime AWpluz eliminated S. aureus.

Some important points should be addressed, such as the relation between bacterial concentration and antimicrobial agent concentration with the ultrasonication time. In this study, a dilution ratio of 1:50 $(20 \mathrm{~mL}$ bacterial suspension in $1000 \mathrm{~mL}$ water) was used with high bacterial concentration ( $3 \times 10^{8}$ cells $\left./ \mathrm{mL}\right)$. Ozone was produced and bubbled into $1 \mathrm{~L}$ sterilized distilled water at a high flow rate as well ( $7 \mathrm{~g} / \mathrm{h}$ ozone $-1.2 \%)$. These values were lower in others studies evaluating different variables (5-7).

It is important to point out the relation between $S$. aureus and oral infections. Staphylococci are facultative anaerobic microorganisms, but they grow optimally under aerobic conditions. They have both a respiratory and a fermentative metabolism. S. aureus produces coagulase, a factor that clots plasma and is considered an indicator of pathogenic potential. Other enzymes with potential importance in microbial pathogenicity include hyaluronidase, lysozyme and lipases. Several toxins are produced by staphylococci: four different hemolysins, an epidermolytic toxin and five types of enterotoxin. S. aureus can produce both invasive and toxigenic diseases, causing boils, carbuncles, impetigo, toxic epidermal necrolyis, abscesses, bacteremia, endocarditis, meningitis, osteomyelitis, pneumonia, toxic shock syndrome and urogenital infections (12).
Previous studies have investigated the effect of ozone on S. aureus mixed with different microorganisms and under different experimental conditions $(6,13,14)$. Lezcano et al. (6) analyzed ozone inactivation of $S$. aureus, $S$. faecalis and C. albicans in water. Water suspension of $10^{4}-10^{6} \mathrm{cfu} / \mathrm{mL}$ of these microorganisms and wild strains were prepared under sterile conditions and treated in a $100 \mathrm{~mL}$ bubble reactor with ozone, achieving concentrations from 0.3 to $2.5 \mathrm{mg}$ of dissolved ozone per liter of water, in contact with microorganisms. Inactivation kinetics of these bacterial strains was similar to Gram-negative bacteria. Firstorder inactivation kinetics respecting to both concentrations of ozone and microorganisms were found, resulting in overall second-order inactivation kinetics. $S$. aureus isolate was more resistant than $S$. faecalis and $C$. albicans strain. The longest time required to achieve total inactivation was $10 \mathrm{~min}$.

Another study (5) investigated ozone inactivation of $P$. aeruginosa, E. coli, S. sonnei and S. typhimurium in water. Environmental isolation of P. aeruginosa was the most resistant and E.coli was the most sensitive wild strain. The longest time required to achieve total inactivation was $35 \mathrm{~min}$. Barros and Fiorini (15) found that $0.12 \%$ chlorhexidine was more effective than $4.5 \mathrm{mg} /$ L ozonated water against $S$. viridans from supragengival dental plaque. A recent study (16) examined the effect of ozonated water against Enterococcus faecalis and Streptcoccus mutans infections in vitro in bovine dentin and found that ozonated water had nearly the same antimicrobial activity as $2.5 \% \mathrm{NaOCl}$ during irrigation, especially when combined with sonication, and showed a low level of toxicity against cultured cells.

The temperature and the time of use of ozone have been widely analyzed. The speed of most chemical reactions increases as the temperature increases. Molecules move slowly at lower temperatures rather than high temperatures and thus may not have enough energy to cause a chemical reaction (17). Considering the experimental conditions tested in this study, temperature variations did not interfere with the results.

The antimicrobial effect of ozone results from oxidation of microbial cellular components. Ozone is a highly reactive form of oxygen that is generated by passing oxygen through high-voltage (17). Oxidation is the removal of electrons from an atom or molecule, a reaction that often produces energy. Several biological oxidations involve the loss of hydrogen atoms (dehy- 
drogenation reactions). Oxygen is essential for the survival of cells that follow aerobic metabolism, although it has a dramatically toxic effect on microaerophiles and anaerobic bacteria. Aerobic respiration involves ATP generation at specific sites in the electron transport chain via oxidative phosporylation (the final electron acceptors include oxygen). Although aerobic bacteria contain a variety of enzymes that protect then from oxygen toxicity, microaerophilic and anaerobic bacteria are devoid of these protective mechanisms. The final electron acceptors in anaerobic respiration include inorganic substrate - sulfate ions, nitrate ions and carbonate ions. Oxygen is not used in fermentation process; anaerobic bacteria use organic compounds as final oxygen acceptor during its energetic metabolism $(12,17)$. Therefore, further research is required to assess the use of ozonated water in different clinical situations.

Under the conditions of this study, the application of ozone in an ultrasonic cleaning system containing either sterile distilled water, vinegar or sterile distilled water + Endozime AWpluz showed antibacterial activity against $S$. aureus.

\section{RESUMO}

O objetivo deste estudo foi avaliar a capacidade do ozônio associado a três diferentes soluções usadas em um sistema de limpeza ultra-sônica em inativar Staphylococcus aureus. Cento e vinte $\mathrm{mL}$ de suspensão com $S$. aureus foram misturadas em $6 \mathrm{~L}$ das soluções experimentais (água destilada esterilizada, vinagre de maça, e água destilada esterilizada + Endozime AWpluz) utilizadas no sistema de limpeza ultra-sônica. O ozônio foi produzido por descarga elétrica através de uma corrente de oxigênio com valor de $7 \mathrm{~g} / \mathrm{h}$ de ozônio (1,2\%) dentro das suspensões microbianas. Um total de $10 \mathrm{~mL}$ de cada solução experimental foram coletados e realizadas cinco diluições em $9 \mathrm{~mL}$ de BHI e incubadas a $37^{\circ} \mathrm{C}$ por $48 \mathrm{~h}$. O crescimento bacteriano foi avaliado pela turbidade do meio de cultura. Ao mesmo tempo, $1 \mathrm{~mL}$ das amostras bacterianas foram coletadas e inoculadas em placas contendo BHIA. Após o período de incubação a $37^{\circ} \mathrm{C}$ por $48 \mathrm{~h}$, realizou-se a contagem de unidades formadoras de colônias (ufc/ $\mathrm{mL}$ ). No teste de diluição em tubos com BHI e placas com BHIA (ufc/mL), quando o ozônio foi empregado, o crescimento bacteriano não foi observado em nenhuma das soluções experimentais. Nas condições deste estudo, a aplicação do ozônio nas soluções experimentais presentes no sistema de limpeza ultra-sônica mostrou atividade antibacteriana sobre S. aureus.

\section{ACKNOWLEDGEMENTS}

The authors would like to acknowledge the companies Odontobrás
Ind. Com. Equip. Med. Odont. Ltda and Eaglesat Tecnologia em Sistemas Ltda for financial support to this study.

\section{REFERENCES}

1. Miller $\mathrm{CH}$, Byrne BE. Infection control strategies for the dental office. In: ADA Guide to Dental Therapeutics. Ciancio S (Editor). 3rd ed. Chicago: ADA Publications; 2003. p. 551-566.

2. Center for Disease Control and Prevention. Recommended Infection Control Practices for Dentistry. MMWR 1993;41(RR-8):1-12.

3. Williams HN, Kelley J, Folineo D, Williams GC, Hawley C, Sibiski J. Assessing microbial contamination in clean water dental units and compliance with disinfection protocol. J Am Dent Assoc 1994;125:1205-1211.

4. Palenik CJ, Burke FJT, Miller CH. Strategies for dental clinic infection control. Dent Update 2000;27:7-15.

5. Lezcano I, Rey RP, Gutiérrez MS, Baluja C, Sánchez E. Ozone inactivation of Pseudomonas aeruginosa, Escherichia coli, Shigella sonnei and Salmonella typhimurium in water. Ozone Sci Eng 1999;21:293-300.

6. Lezcano I, Rey RP, Gutiérrez MS, Baluja C, Sánchez E. Ozone inactivation of microorganisms in water. Gram positive Bacteria and yeast. Ozone Sci Eng 2001;23:183-187.

7. Filippi A. Water disinfection of dental units using ozone Microbiological results after 11 years and technical problems. Ozone Sci Eng 2002;24:479-483.

8. Baysan A, Lynch E. The use of ozone in dentistry and medicine. Prim Dent Care 2005;12:47-52.

9. Nagayoshi M, Fukuizumi T, Kitamura C, Yano J, Terashita M, Nishihara T. Efficacy of ozone on survival and permeability of oral microorganisms. Oral Microbiol Immunol. 2004;19:240-246.

10. Estrela C, Estrela CRA. Control infección em odontologia. São Paulo: Artes Médicas LatinoAmérica; 2005.

11. Garner JS. Guideline for isolation precautions in hospital. Infect Control Hosp Epidem 1996;17:54-80.

12. Gould D, Chamberlaine A. Staphylococcus aureus: a review of the literature. J Clin Nurs 1995;4:5-12.

13. Yamayoshi T, Tatsumi N. Microbicidal effects of ozone solution on methicillin-resistant Staphylococcus aureus. Drugs Exp Olin Res 1993;19:59-64.

14. Murakami $\mathrm{H}$, Mizuguchi $\mathrm{M}$, Hattori $\mathrm{M}$, Ito $\mathrm{Y}$, Kawai $\mathrm{T}$, Hasegawa J. Effect of denture cleaner using ozone against methicillin-resistant Sthaplylococcus aureus and E. coli T1 phage. Dent Mater J 2002;21:53-60.

15. Barros LM, Fiorini JE. Effect of chlorhexidine and ozonated water against $S$. viridans on bacterial supragingival dental plaque. Rev Ass Paul Cir Dent 2000;54:47-52.

16. Nagayoshi M, Kitamura $C$, Fukuizumi $T$, Nishihara $T$, Terashita M. Antimicrobial effect of ozonated water on bacteria invading dentinal tubules. J Endod 2004;30:778-781.

17. Tortora GJ, Funke BR, Case CL. Microbiology: an introduction. 6th ed. Menlo Park: Benjamin/Cummings Publishing Company, Inc.; 1998. 